УДК 620.2:634.7

DOI: $10.15587 / 2313-8416.2015 .37945$

\title{
НОВІ МЕТОДИ ОЦІНКИ ЯКОСТІ ДИКОРОСЛИХ ЯГІД
}

\author{
(C) М. І. Погожих, А. М. Одарченко, Д. М. Одарченко
}

У статті сформульовані наукові підходи щзодо використання нових методів оиінки якості дикорослих ягід, а саме кріоскопічних та оптичних. Доведено, що одержані дані можуть виступати в якості сигнатур для оцінки якості рідкої фази ягід, яку дочільно використовувати під час виробництва напівфабрикатів для консервної та кондитерської промисловості

Ключові слова: кріоскопічні властивості, рідка фаза дикорослих ягід, заморожування, закон Рауля, молярна маса, ефект Тиндаля

The article stated epy scientific approaches to the use of new methods for evaluating the berries quality: cryoscopic and optical. It is proved that the findings can serve as a signature for quality assessment of liquid phase of wild berries, which should be used in the manufacture of semi-finished products for canning and confectionery industry

Keywords: cryoscopic properties, liquid phase of wild berries, freezing, Raoult's law, molar mass, Tyndall effect

\section{1. Вступ}

Останнім часом на ринку України заморожена ягідна продукція займає провідні позиції, що зумовлено розумінням споживачами іï переваг порівняно 3 продуктами харчування інших способів переробки (ферментація, сушіння, консервування) [1].

Сьогодні через високий рівень відхилень від стандартизованої технології, дефіциту якісних продуктів харчування, потоку надходжень імпортних продуктів, які містять замінники натуральної сировини, збільшення фальсифікації призводить до серйозного погіршення якості продуктів харчування.

Фальсифікація натуральних харчових продуктів, як правило, пов'язана 3 імітацією природного походження складових, властивостей та інших ознак i здійснюється в процесі порушення технології, встановленої для відповідних груп харчових продуктів із застосуванням обмеженого переліку харчових добавок та інгредієнтів [2].

Існуючі аналітичні (фізико-хімічні) методи аналізу досить широко використовуються в технологічному контролі виробництва харчових продуктів, що дозволяє жорстко контролювати якість продукту, який випускається. Проте перспективи розвитку експертизи ягідної сировини вимагають розробки нових фізико-хімічних методів аналізу експертизи заморожених харчових продуктів.

У цьому випадку кріоскопічні та оптичні властивості дикорослих ягід можуть бути сигнатурою, яка допоможе керуватися при визначенні якості продуктів переробки дикорослих ягід.

\section{2. Постановка завдання}

Метою роботи було визначення та обгрунтування термодинамічних та оптичних величин, які б виступали сигнатурою якості нових напівфабрикатів з дикорослих ягід.

\section{3. Літературний огляд}

Теоретичні та практичні основи виробництва та експертизи якості напівфабрикатів 3 дикорослих ягід закладені й розвинуті в дослідженнях Р. Ю. Пав- люк, О. І. Черевка, Н. I. Ткач, 3. Р. Сайфуліна, Н. В. Дібрівської, Т. І. Романівської, I. І. Побережець, Н. Дроби та ін.

Проте потенціал використання цінних дикорослих ягід для виробництва напівфабрикатів залишається невичерпним з огляду на їх товарознавчі показники та функціонально-технологічні властивості [3-5].

4. Вивчення кріоскопічних i оптичних властивостей рідкої фази із дикорослих ягід

Об'єктом дослідження були кріоскопічні властивості розчинів плазми журавлини підсніжної та калини звичайної, що підлягали низькотемпературному заморожуванню. Попередньою підготовкою до заморожування було центрифугування механічно подрібнених ягід журавлини підсніжної та калини звичайної. Процес центрифугування здійснювали при швидкості обертання барабану центрифуги $(v)-5000$ об./хв. та протягом 15 хв. до одержання двох фаз: рідкої (в подальшому будемо називати плазмою) та твердої (жмиха). Рідка фаза використовувалася для приготування досліджуваних розчинів. Предметом наукового дослідження була плазма журавлини підсніжної та калини звичайної.

Для дослідження термодинамічних величин обрали розчини однакової концентрації (спів відношення вода:плазма - 1:10), а саме: розчини плазми журавлини підсніжної та калини звичайної, яку отримали шляхом чотириразового циклу заморожування-центрифугування.

Діапазони температур кристалізації та масову частку вимороженої вологи визначали за методикою, яка була розроблена в Харківському державному університеті харчування та торгівлі. Методика дозволяє визначити кількість теплоти, що виді-ляється під час кристалізації вільної вологи в харчовій сировині. Суть цього калориметричного методу полягає у вимірюванні сигналу диферент-ціальної термопари, що реєструє зміну температури потоку холодного повітря, яке оточує досліджуваний зразок. 
Заморожуванню підлягали розчини плазми журавлини підсніжної та калини звичайної масою 25 г, які поміщали в спеціальні пластмасові ємності циліндричної форми та занурювали в калориметр із заданою від'ємною температурою середовища. Процес заморожування вважався завершеним, коли температура в середині досліджуваного зразка досягала значень заданої температури. Після цього здійснювали процес розморожування досліджуваних розчинів шляхом встановлення в камері калориметра температури оточуючого середовища. Експеримент вважався завершеним після досягнення температури в досліджуваному зразку $+20 \pm 2{ }^{\circ} \mathrm{C}$.

В ході експерименту здійснювали контроль середньооб'ємної температури зразків розчинів, а також контролювали температуру вхідної та вихідної 3 камери калориметра суміші повітря та азоту. Реєстрацію здійснювали за допомогою хром елькопелевих термопар у поліетиленовій оболонці 3 діаметром спаювання 0,2 мм. Сигнал від термопар реєстрували цифровим потенціометром, з'єднаним 3 портом ПК. Отримані дані опрацьовували методами математичної статистики та кореляційного аналізу 3 використанням програмного забезпечення MathCad 14.

Загальний вигляд термограм при заморожуванні та нагріванні досліджуваних зразків представлено на рис. 1.

Термограма розбита на дві ділянки, що відокремлені вертикальною лінією: ліва частина ділянка заморожування до постійної температури (для випадку заморожування до $-70{ }^{\circ} \mathrm{C}$ ), права частина - нагрівання (дефростація) за постійної температури, що дорівнює температурі оточуючого середовища. Візуальна інформативність термограм показує, що криві заморожування та розморожування дещо відрізняються за тривалістю: процес розморожування триваліший за заморожування.

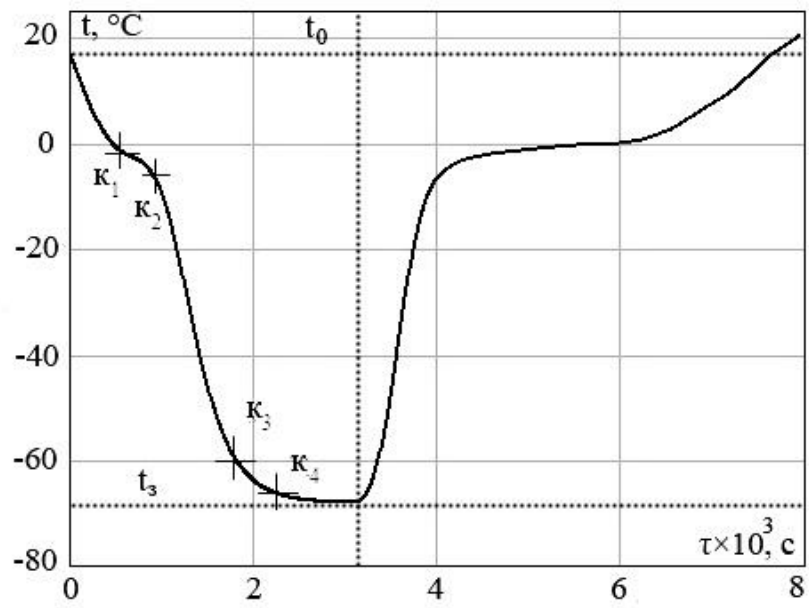

Рис. 1. Середня температура досліджуваного зразка при заморожуванні та нагріванні

В процесі заморожування виділяють три періоди: перший (попереднє заморожування) зниження температури досліджуваного зразка від вихідної до кріоскопічної (проміжок до точки $\mathrm{K}_{1}$ ); другий (заморожування) - період, протягом якого, температура в певному місці продукту майже постійна, оскільки виділення теплоти супроводжується переходом більшої частини води в лід. Тобто до точки $\mathrm{K}_{2}$ відбувається безпосередній процес кристалізації частки води, яку будемо називати «вимороженою». Проміжок між точками $\mathrm{K}_{1}$ та $\mathrm{K}_{2}$ вважається першим діапазоном кристалізації вимороженої води. Третій період заморожування (доморожування) - період, протягом якого температура продукту знижується до заданої кінцевої. Так, якщо розглядати рис. 1 , то після точки $\mathrm{K}_{2}$ далі відбувається охолодження зразка до точки $\mathrm{K}_{3}$, що характеризує початок кристалізації частки «не вимороженої» води. Проміжок від точки $\mathrm{K}_{3}$ до точки $\mathrm{K}_{4}$ - другий діапазон кристалізації води. Після точки $\mathrm{K}_{4}$ відбувається охолодження досліджуваного зразка безпосередньо до заданої температури заморожування.

На кривій нагрівання також можна ідентифікувати аналогічні ділянки, які зумовлені розморожуванням води (таненням льоду).

В методиці використовувався калориметр 3 достатньою чутливістю до реєстрації різниці температур суміші азоту та повітря між входом i виходом у робочу камеру $\Delta \mathrm{t}$. Використовуючи рівняння теплового балансу визначалася кількість вимороженої води на різних ділянках за відносними величинами площ, що обмежені кривими $\Delta \mathrm{t}-\tau$.

На рис. 2 представлено типову криву в координатах $\Delta \mathrm{t}-\mathrm{t}$ зразка для випадку заморожування розчину плазми журавлини підсніжної при $-70{ }^{\circ} \mathrm{C}$.

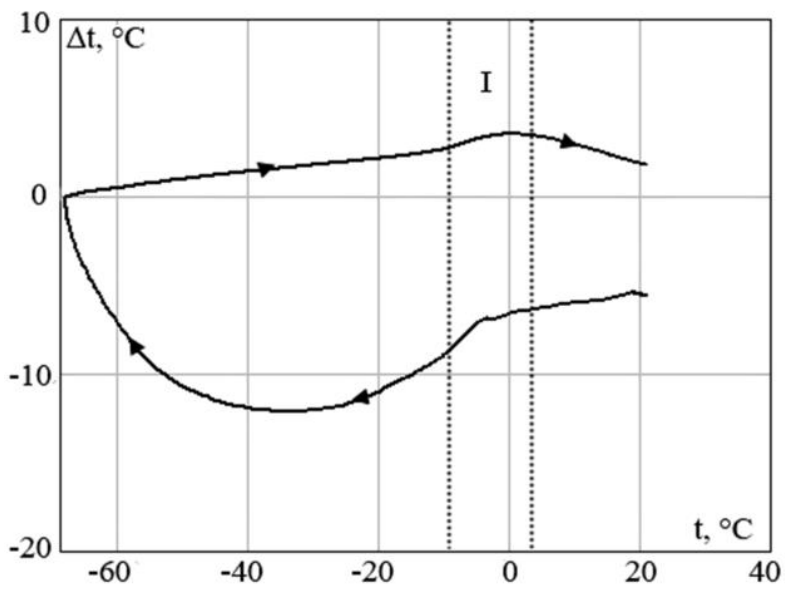

Рис. 2. Різниця температур на вході та виході 3 камери калориметра від температури досліджуваного зразка

Нижня частина рисунку відносно $\Delta \mathrm{t}=0{ }^{\circ} \mathrm{C}$ відповідає охолодженню та заморожуванню, а верхня частина - нагріванню. Як видно, в цій системі координат криві $\Delta \mathrm{t}=f(\mathrm{t})$ достатньо чутливі по відношенню до процесів кристалізації та рекристалізації води в досліджуваних зразках (ділянка I).

На рис. 2 криві заморожування та розморожування розчинів плазми журавлини підсніжної не співпадають, тобто характер теплообміну при заморожувані та розморожуванні різний. 
В табл. 1 представлені результати аналізу термограм процесу заморожування досліджуваних розчинів плазми журавлини підсніжної та калини звичайної.

Проведені кріоскопічні дослідження надали можливість визначити за другим законом Рауля середню молярну масу розчинених речовин, які спричиняють зміщення температури кристалізації води в область низьких температур. Цей закон надає можливість достатньо легко здійснювати експериментальне визначення молярних мас молекул деяких сполук, нездатних до дисоціації в даному розчиннику. Відповідно до цього закону:

$$
\Delta T=k \cdot B=k \frac{g}{\mu},
$$

де $\Delta \mathrm{T}$ - зниження температури замерзання розчину, В полярність розчину, моль/кг; $\mathrm{k}$ - кріоскопічна стала, кг/К; g - число грам розчиненої речовини в $\mathrm{G}$ грамах розчинника, $\mu$ - молярна маса розчиненої речовини.

Величину кріоскопічної сталої можна визначити за емпіричною формулою:

$$
k=\frac{2 \cdot T_{0}^{2}}{G \cdot r},
$$

де $\mathrm{T}_{0}$ - температура затвердіння розчину, $\mathrm{r}$ - теплота кристалізації, $\mathrm{r}=33,3 \cdot 10^{4}$ Дж/кг. речовин:

3 формули (1) визначається молярна маса

$$
\mu=\frac{k \cdot g}{\Delta T} .
$$

Середню молярну масу можна визначити, як

$$
\mu=\frac{\sum_{i=1}^{n} m_{i}}{\sum_{i=1}^{n} v_{i}},
$$

де, $m_{i}$ - маса і-го компонента, $v_{i}$ - число молей і-го компонента.

Звідси видно, що $\mu$ буде залежати від мольної частки компонента в суміші.

В загальному випадку слід враховувати, що досліджувані об'єкти містять дисоціюючі молекули. Тому в закон Рауля слід вводити поправку на так званий ізотонічний коефіцієнт $i$ (фактор ВантГоффа). Це деякий безрозмірний параметр, який пов'язаний зі ступенем дисоціації молекул в розчині, тобто який враховує відносну зміну кількості часточок за рахунок дисоціації. Тому, визначена за цим законом величина $\mu$ в приведених дослідженнях містить в більшій мірі якісну інформацію (сигнатуру), ніж інформацію про абсолютну величину $\mu[6]$.

Кріоскопічна стала та молярна маса розчинених речовин у розчинах плазми журавлини підсніжної та калини звичайної була визначена 3 похибкою $25 \ldots 30$ \% (табл. 2).

Таблиця 1

Результати аналізу кривих заморожування розчинів плазми дикорослих ягід

\begin{tabular}{|c|c|c|c|c|c|}
\hline $\begin{array}{c}\text { Вид } \\
\text { дикорослих ягід }\end{array}$ & $\mathrm{m}_{\text {нав., }} \Gamma$ & $\mathrm{t}_{\text {зам., }}{ }^{\circ} \mathrm{C}$ & $\begin{array}{c}\text { Перший діапазон температур } \\
\text { кристалізації води, }{ }^{\circ} \mathrm{C}\end{array}$ & $\mathrm{t}_{\text {крист., }}$ K & $\begin{array}{c}\text { Масова частка } \\
\text { вимороженої води \% }\end{array}$ \\
\hline Журавлина підсніжна & 25 & -70 & $-1,1 \ldots-4,8$ & 271,9 & 99,94 \\
\hline Калина звичайна & 25 & -70 & $-0,9 \ldots-4,1$ & 272,1 & 99,92 \\
\hline
\end{tabular}

Таблиця 2

Кріоскопічна стала та молярна маса розчинених речовин у розчинах плазми дикорослих ягід

\begin{tabular}{|c|c|c|}
\hline Вид дикорослих ягід & Кріоскопічна стала $(\mathrm{k})$ & $\begin{array}{c}\text { Середня молярна маса розчиненої } \\
\text { речовини }(\mu), \text { г/моль }\end{array}$ \\
\hline Журавлина підсніжна & $25 \pm 5$ & $200 \pm 50$ \\
\hline Калина звичайна & $25 \pm 5$ & $245 \pm 60$ \\
\hline
\end{tabular}

Узагальнення наведених даних свідчить про те, що речовини, які містяться в досліджуваних розчинах мають високу молярну масу (моно- та дисахариди, пектинові речовини тощо) та спричиняють зміщення температурного інтервалу кристалізації в бік більш низьких температур. Отримані результати обгрунтовують можливість використання даної методики для якісного визначення складу продуктів переробки дикорослих ягід.

Особливі оптичні властивості дисперсних систем обумовлені їхніми головними ознаками: дисперсністю та гетерогенністю. Дисперсні системи неоднорідні за фазовим складом, тому мають оптичну неоднорідність. На оптичні властивості дисперсних систем значною мірою впливають структура, розмір та форма частинок. У колоїдних розчинах світлорозсіювання проявляється у вигляді опалесценції - матового світіння, яке можна спостерігати під час освітлення розчину на темному фоні. 3 опалесценцією пов'язане специфічне для колоїдних систем явище - «ефект Тиндаля». При фокусуванні світла в посудині з колоїдним розчином видно смугу, яка світиться, вузьку з боку входу світла та ширшу на виході, що має форму конуса [6, 7].

Визначення кута розсіювання світла («ефект Тиндаля») проводили в плазмі журавлини підсніжної та калини звичайної, що підлягала центрифугуванню та багаторазовому заморожуванню. Через прозору посудину (мірний циліндр) 3 досліджуваним зразком пропускають промінь світла та спостерігають його розсіювання. Промінь повинен мати вигляд конуса чи трикутника, який видно на темному фоні. Потім вимірюють його довжину (b) від вершини до будьякої обраної точки та основу (а) (рис. 3).

Помутніння плазми може бути викликано грубодисперсними частинами плодової тканини або розчиненими в ній колоїдними часточками, що викликають світлорозсіювання. Причиною опале- 
сценції є розсіювання світла внаслідок його дифрак-ції в мікронеоднорідному середовищі колоїдного розчину.

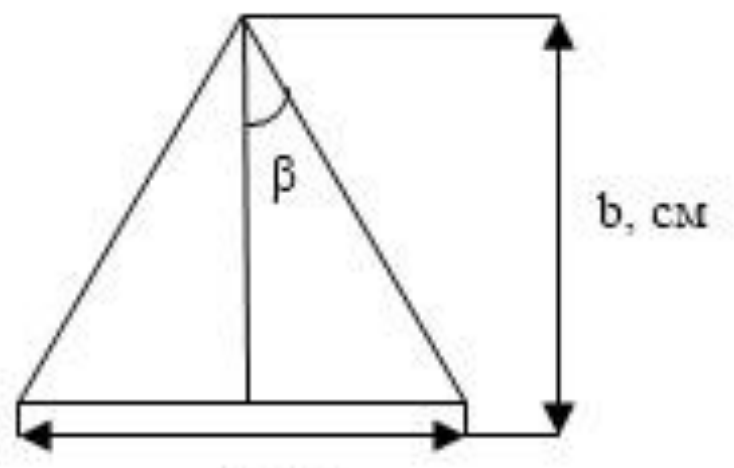

a, $\mathrm{CM}$

Рис. 3. Схема визначення кута розсіювання світла

Плазма дикорослих ягід являє собою колоїдний розчин, що містить часточки невеликих розмірів, в результаті чого рідина може здаватися прозорою, проте ці часточки $є$ не окремими молекулами, а їх скупченням.

Тангенс кута розсіювання світла розраховували за формулою:

$$
\operatorname{tg} \beta=\frac{a}{2 b},
$$

Отримані результати зображено на рис. 4.

3 рис. 4 видно, що кут розсіювання світла в плазмі калини звичайної дещо більший в порівнянні 3 плазмою журавлини підсніжної. Це, очевидно, пояснюється тим, що інтенсивність розсіювання світла (при постійних параметрах падаючого світла) залежить від числа та розміру часточок, що здатні його розсіювати.

Експериментально підтверджено, що циклічність заморожування однаково впливає на значення кута розсіювання світла в плазмі дикорослих ягід: $\beta$ зменшується зі збільшенням циклів заморожування. Це зумовлено тим, що після кожного наступного центрифугування та заморо-жування до $-20^{\circ} \mathrm{C}$ часточки, що здатні розсіювати світло, видаляються разом $з$ утвореним осадом.

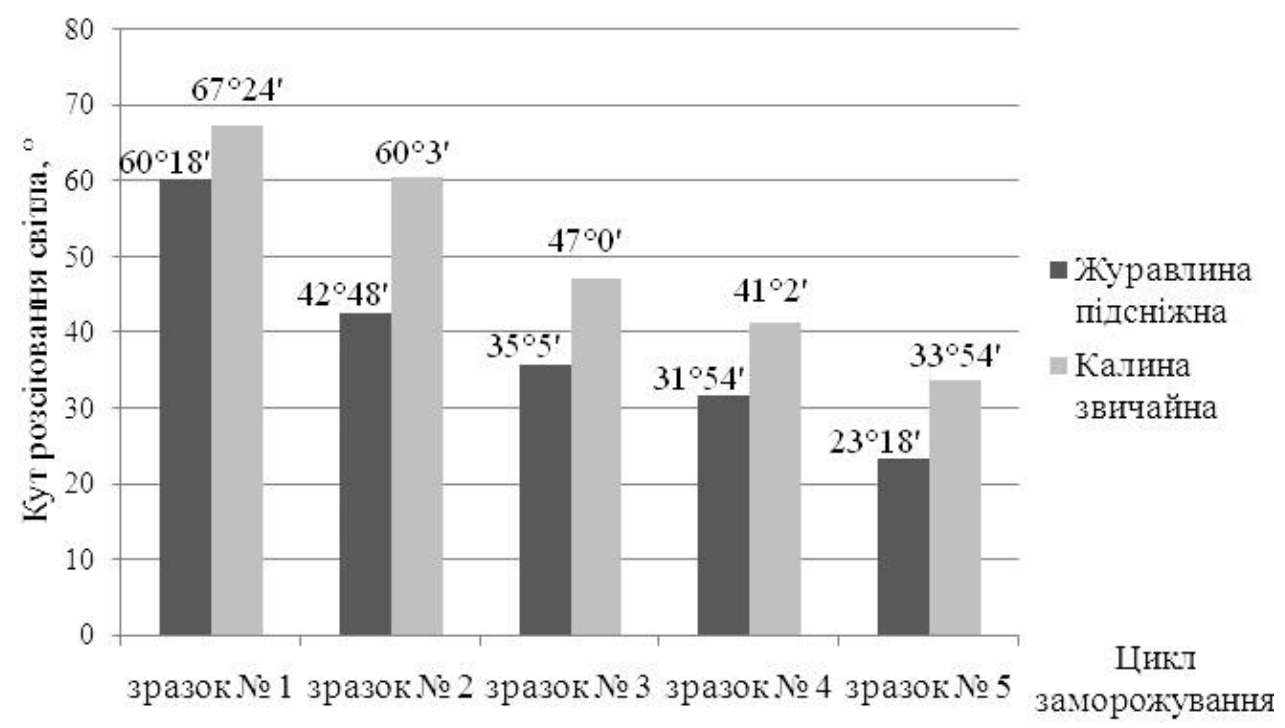

Рис. 4. Кут розсіювання світла в плазмі журавлини підсніжної та калини звичайної

\section{5. Висновки}

Проведеними дослідженнями та встанов-леними закономірностями науково обгрунтовано доцільність використання пропонованих кріоскопіч-них та оптичних методів для якісного аналізу складу напівфабрикатів 3 дикорослої ягідної сировини. Визначена кріоскопічним шляхом середня молярна маса розчинених речовин та оптичним методом - кут розсіювання світла, можуть виступати в якості сигнатур для товарознавчої оцінки якості плазми ягід, яку доцільно використовувати у виробництва напівфабрикатів для консервної та кондитерської промисловості. Пропоновані методи, пов'язані з вирішення проблеми якості розроблених напівфабрикатів та мають перспективи подальшого дослідження і розвитку.

\section{Література}

1. Орлова, Н. Я. Заморожені плодоовочеві продукти: проблеми формування асортименту та якості
[Текст] / Н. Я. Орлова, С. О. Белінська. - К. : Київ. нац. торг.-екон. ун-т, 2005. - $336 \mathrm{c}$.

2. Руководство по методам анализа качества и безопасности пищевых продуктов [Текст] / под ред. И. М. Скурихина, В. А. Тутельяна. - М. : Брандес; Медицина, 1998. - С. 45-67.

3. Орлова, Н. Я. Продовольчі товари. Фрукти, ягоди, овочі, гриби та продукти їхньої переробки [Текст] : підручник / Н. Я. Орлова, П. Х. Пономарьов; 2-е вид., переробл. та допов. - К. : Київ. нац. торг.-екон. ун-т, 2007. $-416 \mathrm{c}$.

4. Хомич, Г. П. Використання дикорослої сировини для забезпечення харчової продукції БАР [Текст]: монографія / Г. П. Хомич, Н. І. Ткач. - Полтавський ун-т споживчої кооперації України. - Полтава : ПУСКУ, 2009. - 159 с.

5. Дібрівська, Н. В. Технологія функціональних напівфабрикатів добавок із дикорослих ягід 3 використанням обробки в змінному електромагнітному полі [Текст]: дис. ...канд. техн. наук / Н. В. Дібрівська. Київ, 2009. - 224 с. 
6. Телеснин, Р. В. Молекулярная физика [Текст] / Р. В.Телеснин. - М. : Высшая школа, 1965. - 297 с.

7. Кругляков, П. М. Физическая и коллоидная химия : учебное пособие [Текст] / П. М. Кругляков, Т. Н. Хаскова. - М. : Высшая школа, 2005. - 319 с.

\section{References}

1. Orlova, N. Ya., Belins'ka, S. O. (2005). Zamorozheni plodoovochevi producty: problemi formuvannya assortmenty i yakosti [Frozen vegetables products: problems and quality product range]. Kyiv, Ukraine: Kyiv National University of Trade and Economics, 336.

2. Skuryhyna, I. M., Tutelyana, V. A. (Eds.) (1998). Rukovodstvo po methodan analysa kachestva i bezopasnosty pischevikh productov [Manual methods of quality and food safety]. Moscow: Brandes; Medicine, 45-67.

3. Orlova, N. Ya., Ponomarev, P. Kh. (2007). Prodovolchi tovary. Fructy, yagody, ovochi, griby ta producty ih pererobki [Frozen vegetables products: problems and quality product range]. Kyiv, Ukraine: Kyiv National University of Trade and Economics, 416.

4. Khomich, G. P., Tkach, N. I. (2009). Vikoristannya dikorosloï sirovini dlya zabezpechennya harchovoi produktsii BAR [The use of wild raw materials for the food BAP]. Poltava, Ukraine: Poltava University of Consumer Cooperatives in Ukraine, 159.

5. Dibrivs'ka, N. V. (2009). Tehnologiya funktsionalnih napivfabrikativ dobavok iz dikoroslih yagid s vikoristannyam obrobki y zminnomu elektromagnitnomu poli [Technology of the semi functional additives with berries processing using an alternating electromagnetic field]. Kyiv, 224.

6. Telesnin, R. V. (1965). Molekulyarnaya physica [Molecular physics]. Vischa Schola, 297.

7. Kruglyakov, P. M., Haskovo T. N. (2005). Physicheskaya i kolloydnaya khimia [Physical and Colloid Chemistry]. Moskow, Russia: High School, 319.

Погожих Микола Іванович, доктор технічних наук, професор, кафедра енергетики i фізики, Харківський державний університет харчування та торгівлі, вул. Клочківська, 333, м. Харків, Україна, 61051

E-mail: laboratory119@mail.ru

Одарченко Андрій Миколайович, доктор технічних наук, доцент, кафедра товарознавства, управління якістю та екологічної безпеки, Харківський державний університет харчування та торгівлі, вул. Клочківська, 333, м. Харків, Україна, 61051

Одарченко Дмитро Миколайович, кандидат технічних наук, доцент, кафедра товарознавства, управління якістю та екологічної безпеки, Харківський державний університет харчування та торгівлі, вул. Клочківська, 333, м. Харків, Україна, 61051

\section{УДК 504.4.054}

DOI: 10.15587/2313-8416.2015.37207

\section{УТОЧНЕНИЕ ПОНЯТИЯ «МАКСИМАЛЬНО ЗАГРЯЗНЕННАЯ ЧАСТЬ ПОТОКА ВОДЫ» В ЗАДАЧАХ РАСЧЕТА ДОПУСТИМОГО СБРОСА СТОЧНЫХ ВОД В ВОДОТОК}

\section{(C) Н. И. Адаменко, О. А. Проскурнин}

В статье поднимается вопрос о формализации понятия «максимально загрязненной части потока водыl» в задачах расчета допустимого сброса сточных вод в водотоки. Предлагается в качестве максимально загрязненной части потока рассматривать окрестность точки экстремального загрязнения, в которую попадает заданный процент вещества, поступающего от источника загрязнения. Приводится пример использования предлагаемого подхода в задаче расчета допустимого сброса сточных вод

Ключевые слова: сточные воды, максимально загрязненная часть потока, контрольный створ, плотность распределения, допустимая концентрация

The problem of formalizing the concept of "maximally contaminated part of the water flow" in the task of allowable discharge calculating of wastewater into watercourses is considered in the article. It is proposed to consider a neighborhood of point of extreme pollution, which gets a specified percentage of the substance coming from the source of contamination, as the most polluted part of the flow. An example of the use of proposed approach to the problem of calculating the allowable discharge of wastewater is given.

Keywords: wastewater, most polluted part of the flow, monitoring section, distribution density, allowable concentration

\section{1. Введение}

Загрязнение водных объектов (ВО) Украины, в частности, рек сточными водами $(\mathrm{CB})$ является одной из наиболее острых экологических проблем. С целью регулирования данного процесса и недопущения чрезмерного загрязнения ВО для предприятийводопользователей разрабатываются и утверждаются предельно допустимые сбросы (ПДС) загрязняющих 